\title{
Moral politics, moral decline and anti-social behaviour
}

\author{
Andrew Millie* \\ University of Glasgow
}

\begin{abstract}
This short article focuses on the moral politics associated with anti-social behaviour (ASB) and an assumed moral decline in Britain. The rhetoric and policy of Labour and the Conservatives are considered including talk of 'respect' and a 'broken society'. The 2010 General Election provides the context. It is contended that such civilising agendas are only meaningful if the government of the day can lead by example. Rather than focusing on an assumed moral decline by trying to enforce standards of behaviour, an alternative is suggested that acknowledges that not all youthful (mis)behaviour given the ASB badge is necessarily problematic. Policies that promote social connectedness, inter-group understanding and tolerance are suggested, and the sort of mutual respect originally put forward by Sennett (2003). The promotion of 'togetherness in difference' (Sandercock, 2003) that is characteristic of cosmopolitan urbanism is suggested as a more optimistic position to take than a focus on moral decline.
\end{abstract}

Keywords: Anti-social behaviour; politics; moral decline; populism.

\section{Introduction}

Developments in criminal policy have a long history of entanglement with the particular politics of the day with influences including vote-chasing populism, political ideology and moral politics. These influences can become a blur, but often it is simple vote chasing with politicians trying to second guess the voters' wishes by promoting ever tougher sanctions - trying to outdo each other in being more and more punitive, and in so doing becoming ever more populist (e.g. Bottoms, 1995; Garland, 2001; Roberts, et al., 2002). Throughout the 1990s crime in Britain became increasingly politicised with a fight between New Labour and the Conservatives for an assumed popular vote, with greater emphasis on tougher sanctions (Millie, 2008). For New Labour one way this populism was translated into policy was a focus on anti-social behaviour (ASB) (Jamieson, 2005; Millie, 2009a). Yet, despite a tendency towards populism, politicians ${ }^{1}$ were still also influenced by ideology and moral politics - albeit to varying degrees of conviction. For instance, Tony Blair was famously influenced by Christian Socialism in combination with elements of Etzioni's communitarianism (1993), Giddens' 'third way' (1998) and Sennett's (2003) mutual respect. Furthermore, both 


\section{p. 7. Moral politics, moral decline and anti-social behaviour}

Labour and the Conservatives have been influenced by American New Right writing on underclass (Murrey, 1990) and 'broken windows' (Wilson and Kelling, 1982). Both of these perspectives assume there has been a moral decline in society, with underclass theory focused on the type of people caught up in moral decline, and 'broken windows' describing the mechanism through which decline is thought to take place. This short article focuses on this assumed moral decline and the moral politics associated with ASB. For the British ASB agenda an assumed moral decline translated into a moral politics focused on the behaviour of youth, along with a concern for parenting and 'family values'. The tendency was for punitive responses to both with an assumption that good behaviour (and good parenting) can be enforced. At the time of writing in early 2010 there was a looming general election in Britain and it was not at all certain who would win. However, it is worth noting that at the last general election in 2005 all three main political parties - Labour, Conservatives and Liberal Democrats - had embraced the need to tough action on ASB (Millie, 2008).

The ASB agenda was one of the things that defined Labour's approach to crime and disorder in the first decade of the 21st Century (Squires, 2008; Burney, 2009; Millie, 2009a) and it was an agenda closely allied to Tony Blair. It followed pressure from local politics and from social landlord providers (Burney, 2009), although the national response was distinctly populist characterised by 'tough talking' rhetoric and an emphasis on enforcement. The political landscape seemed to change following Gordon Brown's success at becoming Prime Minister in 2007; and the Blairite 'tough talking' populism appeared to be replaced by a softer approach when Brownite minister Ed Balls was reported as stating, "It's a failure every time a young person gets an ASBO. It's necessary - but it's not right" (reported by Blackman in the Daily Mirror, 2007). Furthermore, a new Youth Taskforce Action Plan (Youth Taskforce, 2008) offered greater emphasis on prevention and support, although a focus on "tough enforcement" remained and support was to be "non-negotiable" (p.5). And while some ministers were using softer language, others persisted with talk of being tough on ASB; as Jacqui Smith (2008) stated as Home Secretary, "ASB has no place in our daily lives. No-one should have to put up with it. And no-one should think they can get away with it either"2. This toughness was continued by Alan Johnson when he became Home Secretary in June 2009. Later that month in an interview in The Times (Ford, 2009) Johnson commented, "we have kind of coasted a bit. The coasting has allowed some of our critics to suggest that antisocial behaviour [policy] has not achieved very much. Well it has." However, due to there being bigger news stories - notably the economy and the major scandal over MPs' expenses - this statement did not receive a great deal of attention in the wider media. And by the autumn of 2009 the Conservatives had been gaining attention for their 'broken society' agenda.

In September 2009 the inquest of Fiona Pilkington was reported, a woman who killed herself and her disabled daughter after repeated harassment from local youths. It was generally reported as ASB (e.g. Daily Mirror, 2009), although I suggest it was something far more serious amounting to a campaign of harassment or 'hate crime' (e.g. Iganski, 2008) (a few journalists have described the case as 'disability hate crime' - e.g. Williams, 2009). The day after the inquest was reported, Gordon Brown delivered his speech to the Labour Party Conference as Prime Minister reasserting the need for tough action on ASB, that "whenever and wherever there is antisocial behaviour, we will be there to fight it". It was classic populist rhetoric, something picked up by the BBC's Home Editor, Mark Easton, writing in his online blog the same day:

It seems there is a big red button marked "ASB" at Labour HQ. The sign next to it reads: "In case of electoral emergency, press here". No surprise that Gordon Brown is today thumping the anti-social behaviour (ASB) button with a mallet. It is a tactic which [has] been instrumental in Labour's success for more than a 
decade. Even though many Brownites had previously sniffed at a policy they regarded as punitive and populist, needs must. A Blairite invention has been wheeled to the frontline for the fightback (Easton, 2009).

On 13 October 2009, when launching a 'new' push on ASB (under the banner “Tackling Not Tolerating"), Home Secretary Alan Johnson used the Pilkington case to demonstrate why the government had to return to the issue of ASB (Travis, 2009a). As part of Johnson's new 'get tough' agenda he promised to prosecute all ASBO breaches and to make Parenting Orders mandatory accompaniments for all juveniles on ASBOs. As Easton (2009) had pointed out, the pre-election ASB button had been well and truly pressed. Easton went further in his assessment, suggesting that, "It appears that we have decisively moved into an era when enforcing 'proper behaviour' is the business of the state." Easton had identified a noticeable shift in politics; but where I believe he was wrong is that the moral politics of enforcing 'proper behaviour' had been in place for some time and had been embraced by all the main parties.

\section{Moral decline and moral politics}

For Labour and the Conservatives the assumption was that Britain had witnessed sustained moral decline as exemplified by problems of ASB, and the situation would only change through state-enforced moral improvement. For instance, former Labour Home Secretary Jack Straw (1996) claimed that there was a "rising tide of disorder [that] is blighting our streets, parks and town centres". For David Blunkett (2004) ASB was "bedevilling our communities", and for Tony Blair (2004) a "scourge of anti-social behaviour affects us all". Fellow Labour MP Frank Field (2003: 126) went further, claiming there was a "plague of disorder which now marks the lives of so many the likes of which Britain has not seen for well over a century". According to Pearson (2009: 41) it was a view that, "young people no longer respect the law, no longer respect their parents and neighbours, they no longer show any obedience to authority in all its forms, there is now a carnival of disorder in the streets of the 'broken' society" (emphasis in original).

But, as Pearson (1983; 2009) and others (e.g. Cohen, 1972) have clearly demonstrated, children and young people have been seen to be pushing boundaries for a very long time. Furthermore, according to British Crime Survey measures of perception (Millie, et al., 2005), ASB is not a major concern for the majority - so talk of plagues, rising tides and 'bedevilling' may have been overselling it. Such talk also ran the risk of fuelling public concern. But the view from Labour was that something had gone fundamentally wrong with British society resulting in a moral (and behavioural) decline - especially among our youth. The government's response centred on legislation and was to enforce standards of behaviour. For Blair (2003) the solution was also the moral imperative to instil respect (see Millie, 2009b); as Sennett (2005) has observed, "throughout his career Tony Blair has worried about how government might enforce morality". The notion that morality can be enforced and that people can be made more respectful is a strange one. But not to be outdone, the Conservatives with their 'broken society' agenda have come to a similar conclusion (Conservatives, 2010a; 2010b). The 'broken society' agenda is intrinsically one of a moral decline, and is clearly influenced by the 'broken windows' perspective, as demonstrated by the following statement from Chris Grayling (2009a), speaking as Shadow Home Secretary, that, "Changing what we have called the broken society will be a long and difficult process. But one step we can take quickly is to go to war on antisocial behaviour. Because the minor criminality committed by younger teenagers so often leads to worse if it goes unchecked." 
Much of the Tory policy development started life in Conservative MP lain Duncan Smith's Centre for Social Justice. In a joint publication with the left-of-centre think tank the Smith Institute, Duncan Smith (2008: 9) has also shown the influence of underclass thinking, where there is a, "creeping expansion of this underclass: the way 'decent' people are sucked into and governed by the 'code of the street'". Furthermore, according to Duncan Smith (2008: 9) - drawing on the work of Anderson (1999) - "the most powerful counteracting force to the negative influences of the inner city [is] a strong, loving, 'decent' family, committed to mainstream, pro-social values". The Conservatives have been using language and rhetoric similar to Labour, and for Cameron (2008) the moral decline is fact: "When in one generation we seem to have abandoned the habits of all human history that in a civilised society, adults have a proper role - a responsibility - to uphold rules and order in the public realm".

Against this backdrop it seems that, if elected, the Conservatives will be just as punitive and populist as Labour has been, that - to use Grayling's words - they will "go to war" on anti-social young people (and their parents). This is despite Cameron's (2006) famous defence of hoodie wearing young people - in what the media labelled his 'hug a hoodie' speech - that "adult society's response to the hoodie shows how far we are from finding the long-term answers to put things right". Punitive populism is demonstrated by the promotion of a new 'Grounding Order' in the Conservatives' Manifesto (2010b: 56), an 'instant sanction' curfew issued by the police to anti-social young people. This appears to be a mix between existing Dispersal Order, Fixed Penalty Notice, and Local Child Curfew Scheme powers ${ }^{3}$ - regardless of the fact that child curfews have not been popular with Local Authorities, with none set up since being introduced with the 1998 Crime and Disorder Act (according to the YJB website, accessed March 2010). But despite promoting such punitive measures there are glimpses of hope. Grayling has also stated that:

The vast majority of the teenagers who hang around in our communities are decent law abiding young people who are doing nothing wrong. Many acts which annoy are not acts of anti-social behaviour. There's a real danger that we perceive a risk from groups of perfectly decent young people who are doing nothing more than hanging around and chatting. Then there is the low level antisocial behaviour which can be found in most areas. Where the perpetrators are a headache - but aren't criminals in the making. (2009b).

This was encouraging; and elsewhere Grayling has stated that, "What we don't want to do is criminalise those young people very early on in their lives" (2009c). However, as Travis has stated, writing for The Guardian (2009b), "As the general election approaches you can expect to hear rather less about "hug a hoodie" and rather more about "mug a hoodie" when it comes to the Conservatives' approach to law and order". The proposed Grounding Order is a case in point.

The moral politics adopted by both Labour and the Conservatives - as exemplified by the respect and broken society agendas - is a tricky game to play and perhaps ought to be avoided by politicians. Government-led civilising agendas are only meaningful if the government of the day can lead by example. As the expenses scandal of 2009 showed, politicians are not coming to this from a position of strength. Furthermore, both Labour and the Conservatives have utilised a discourse that divides a (supposed) law abiding or 'decent' us against a disrespectful or anti-social underclass. I suggest that such an approach is dishonest and can result in the labelling of minority populations as stigmatised 'others' with their 'unwanted' behaviour leading to censure. In policy and political rhetoric on ASB the main targets have been young people and their parents - or more precisely following underclass theory, the young working class and single mothers. 


\section{Discussion and conclusions}

An alternative response - and a challenge to whoever wins the election - is to acknowledge that not all youthful (mis)behaviour given the ASB badge is necessarily problematic. For example, not all politicians were involved in the 2009 expenses scandal, yet the stereotype of a British politician has become someone who is money grabbing and with questionable morals. Politicians and policy makers would do well to recognise that the assumption that all young people hanging around are anti-social is similarly an inaccurate stereotype (see Mackenzie, et al., 2010). On this front the above quote from Grayling is encouraging as young people need to be able to explore boundaries without necessarily being criminalised. There still needs to be intervention for serious and persistent ASB that has a detrimental impact on others; however there is a great deal below this - including young people 'hanging around' - that should not lead to censure and could be tolerated.

While forms of ASB can be regarded as problematic in themselves, according to Mackenzie et al., (2010) some behaviours - such as young people congregating, or parents raising 'problem' children - also act as metaphors for wider social concerns or social breakdown. But such views may be ill-informed or based on existing prejudices or stereotypes, and in such circumstance responding to the majority view will not produce just outcomes; as Loader (2006: 207) has observed concerning public demands for policing, these are "not infrequently motivated by parochial desires for injustice, xenophobic antipathy toward others, or unattainable fantasies of absolute security." Such views will need to be challenged. For Mackenzie et al., (2010) solutions lie in promoting social connectedness - that, the more people (including politicians) who can understand other perspectives, the more behaviours are seen as simply different rather than anti-social.

The result will be an increase in inter-group understanding and tolerance, and the sort of mutual respect promoted by Sennett (2003) - and perhaps ought to have been central to New Labour's respect agenda (Respect Task Force, 2006; Millie, 2009b) rather than a focus on moral decline and enforcing standards of behaviour. Writings on cosmopolitan urbanism may offer some help here (e.g. Sandercock, 2003; Binnie et al., 2006; Millie, 2009c). According to Sandercock (2003: 2), her cosmopolitan utopia - what she called 'Cosmopolis' - is a place that promotes "genuine acceptance of, connection with, and respect and space for the cultural other, and the possibility of working together on matters of common destiny, the possibility of a togetherness in difference". This is certainly a more optimistic position to take than a politics of moral decline. The notion of "togetherness in difference" is a challenge to the populist punitiveness often associated with political electioneering and to a moral politics centred on enforcing 'proper behaviour'.

\section{Notes}

1 For this article the focus is on Westminster politics as this is most relevant to the 2010 General Election. However it is acknowledged that since devolution other approached to ASB have emerged - for instance, Wales appears to be following a less punitive path and the Scottish Government (2009) is following its "Promoting Positive Outcomes" agenda.

2 Tough political rhetoric was not always matched by local practice. By this time many local ASB practitioners had accumulated a decade's worth of experience and in some instances less punitive, inclusionary and preventative approaches were being developed at the local level. 
3 Under Local Child Curfew Scheme conditions, all young people are banned from being in a designated public place between specified hours (e.g. from 9pm to 6am) unless accompanied by an adult. As noted, these powers have not proved popular. Dispersal Orders are similar area-based restrictions that can be imposed in areas where ASB is deemed to be particularly problematic. They are frequently applied to city centre or housing estate locations where police officers/PCSOs are given extra powers to disperse. The Orders also have a curfew-type element, although following legal clarification this was deemed to be non-arbitrary and therefore not a curfew, with powers restricted to only those young people thought a risk (or at risk) of ASB. The proposed 'Grounding Orders' appear to have a lot in common with such restrictions. Being a form of 'instance sanction' they are also similar to Fixed Penalty Notices (FPNs) which are summary on-the-spot fines, usually issued for issues of environmental ASB (for more detail see Millie, 2009a).

* Correspondence Address: Andrew Millie, Department of Urban Studies, University of Glasgow, 25 Bute Gardens, Glasgow, G12 8RS. Email: a.millie@lbss.gla.ac.uk.

\section{References}

Anderson, E. (1999) Code of the Street: Decency, Violence, and the Moral Life of the Inner City. New York: W. W. Norton.

Binnie, J., Holloway, J., Millington, S. and Young, C. (2006) Cosmopolitan Urbanism. London: Routledge.

Blackman, O. (2007) Asbos are a failure, Daily Mirror, 27 July. Available at: www.mirror.co.uk/news/top-stories/2007/07/27/asbos-are-a-failure-11587519528541.

Blair, T. (2003) Prime Minister's speech on anti-social behaviour. QEll Centre: London, 14 October, Available at: www.pm.gov.uk/output/Page4644.asp

Blair, T. (2004) PM's speech on anti-social behaviour, 28 October, Available at: www.number-10.gov.uk/output/Page6492.asp

Blunkett, D. (2004) Speech by the Rt. Hon. David Blunkett MP, New Local Government Network, 22 January.

Bottoms, A. (1995) The philosophy and politics of punishment and sentencing, in: C. Clarkson and R. Morgan (eds.), The Politics of Sentencing Reform. Oxford: Clarendon Press.

Brown, G. (2009) Gordon Brown's speech to Labour Conference, 29 September, Available at: www.labour.org.uk/gordon-brown-speech-conference,2009-09-29

Burney, E. (2009) Respect and the politics of behaviour, in A. Millie (ed.), Securing Respect: Behavioural Expectations and Anti-Social Behaviour in the UK. Bristol: Policy Press.

Cameron, D. (2006) Making our country a safe and civilised place for everyone, Speech to the Centre for Social Justice, 10 July, www.conservatives.com.

Cameron, D. (2008) David Cameron: Conference Speech 2008, 1 October, Available at: www.conservatives.com/News/Speeches/2008/10/David_Cameron_Conference _Speech_2008.aspx

Cohen, S. (1972) Folk Devils and Moral Panics: The Creation of Mods and Rockers. London: MacGibbon and Kee Ltd.

Conservatives (2010a) Conservatives Draft Manifesto 2010 - Chapter 2: Mending Our Broken Society. London: The Conservative Party.

Conservatives (2010b) Invitation to Join the Government of Britain: The Conservative Manifesto 2010. London: The Conservative Party. 
Daily Mirror (2009) Police apologise after Fiona Pilkington inquest verdict criticises their failure. Daily Mirror Online. Available at: www.mirror.co.uk.

Duncan-Smith, I. (2008) How can we mend a broken society? in: G. Allen and I. Duncan-Smith (eds.) Early Intervention: Good Parents, Great Kids, Better Citizens. London: The Centre for Social Justice and The Smith Institute.

Easton, M. (2009) The politics of proper behaviour. BBC News Online Blog, 29 September, Available at: www.bbc.co.uk/blogs/thereporters/markeaston/2009 /09/the_politics_of_proper_behavio.html

Etzioni, A. (1993) The Spirit of Community: The Reinvention of American Society. New York: Touchstone.

Field, F. (2003) Neighbours from Hell. London: Politico's.

Ford, R. (2009) Alan Johnson to tackle antisocial behaviour as top priority. The Times, 22 June, Available at: www.timesonline.co.uk/tol/news/politics/article6549664 ece

Garland, D. (2001) The Culture of Control: Crime and Social Order in Contemporary Society. Oxford: Oxford University Press.

Giddens, A. (1998) The Third Way: The Renewal of Social Democracy. Cambridge: Polity Press.

Grayling, C. (2009a) Chris Grayling: Tackling antisocial behaviour. Speech 9 April, Available at: www.conservatives.com/News/Speeches/2009/04/Chris Grayling Tackling anti-social behaviour.aspx

Grayling, C. (2009b) Chris Grayling: Not enough being done to tackle anti-social behaviour. Speech 14 July, Available at: www.conservatives.com/News/ Speeches/2009/07/Chris Grayling Not enough being done to tackle antisocial behaviour.aspx

Grayling, C. (2009c) Contribution to, David Cameron and Chris Grayling on stopping antisocial behaviour, for Webcameron UK. Available at: www.youtube.com/user/webcameronuk\#p/search/1/pMLPOK3HvLc

Iganski, P. (2008) Hate Crime and the City. Bristol: Policy Press.

Jamieson, J. (2005) New Labour, youth justice and the question of respect. Youth Justice, 5, 3, 180-193.

Loader, I. (2006) Policing, recognition, and belonging. The Annals of the American Academy of Political and Social Science, 605, 1, 201-221.

Mackenzie, S., Bannister, J., Flint, J., Parr, S., Millie, A. and Fleetwood, J. (2010) The Drivers of Perceptions of Anti-Social Behaviour Home Office Research Report 34. London: Home Office.

Millie, A. (2008) Crime as an issue during the 2005 UK general election. Crime, Media, Culture, 4, 1, 101-111.

Millie, A. (2009a) Anti-Social Behaviour. Maidenhead: Open University Press.

Millie, A. (2009b) Securing Respect: Behavioural Expectations and Anti-Social Behaviour in the UK. Bristol: Policy Press.

Millie, A. (2009c) Respect and city living: Contest or cosmopolitanism? in: A. Millie (ed.), Securing Respect: Behavioural Expectations and Anti-Social Behaviour in the UK. Bristol: Policy Press.

Millie, A., Jacobson, J., McDonald, E. and Hough, M. (2005) Anti-Social Behaviour Strategies: Finding a Balance. Bristol: Policy Press.

Murray, C. (1990) The British Underclass. The Public Interest, 99 (Spring), 4-28.

Pearson, G. (1983) Hooligan: A History of Respectable Fears. Basingstoke: Macmillan.

Pearson, G. (2009) A Jekyll in the classroom, a Hyde in the street: Queen Victoria's hooligans', in: A. Millie (ed.), Securing Respect: Behavioural Expectations and Anti-Social Behaviour in the UK. Bristol: Policy Press.

Respect Task Force (2006) Respect Action Plan. London: Home Office.

Roberts, J., Stalans, L., Indermaur, D. and Hough, M. (2002) Penal Populism and Public Opinion. Oxford: Oxford University Press. 
Sandercock, L. (2003) Cosmopolis II: Mongrel Cities of the 21st Century. London: Continuum.

The Scottish Government (2009) Promoting Positive Outcomes: Working Together to Prevent Antisocial Behaviour in Scotland. Edinburgh: The Scottish Government.

Sennett, R. (2003) Respect: The Formation of Character in an Age of Inequality. London: Penguin Books.

Sennett, R. (2005) What our grannies taught us: The government cannot enforce respect when it has failed to earn it. The Guardian, 19 May, Available at: www.guardian.co.uk/politics/2005/may/19/uk.comment

Squires, P. (2008) ASBO Nation: The Criminalisation of Nuisance. Bristol: Policy Press.

Straw, J. (1996) Speech by Shadow Home Secretary, Jack Straw, speech to the NACRO AGM. Available at: www.prnewswire.co.uk/cgi/news/release?id=19432

Travis, A. (2009a) Alan Johnson criticises police attitudes on antisocial behaviour. The Guardian, 13 October, Available at: www.guardian.co.uk/politics/2009/oct/13/ alan-johnson-police-antisocial-behaviour

Travis, A. (2009b) What would the Conservatives do for law and order? The Guardian, 8 October. Available at: www.guardian.co.uk/society/2009/oct/08/conservativeslaw-order-crime

Williams, R. (2009) Pilkington case may be a Lawrence moment for disability hate crime. The Guardian, 28 September, Available at: www.guardian.co.uk/uk/2009 /sep/28/fiona-pilkington-inquest-disability-hate

Wilson, J. Q. and Kelling, G. L. (1982) Broken windows: The police and neighbourhood safety. The Atlantic Monthly, March, 249, 3, 29-38.

YJB Website (2010) Youth Justice System: Local Child Curfew. Accessed March 2010, Available at: www.yjb.gov.uk/en-gb/yjs/SentencesOrdersandAgreements/Local ChildCurfew/

Youth Taskforce (2008) Youth Taskforce Action Plan: Give Respect, Get Respect Youth Matters. London: DCSF. 